\title{
Effect of Different Cavity Disinfectants on Microleakage
}

\author{
Samican Unal ${ }^{1}$, Sema Yazici Akbiyik², Elif Pinar Bakir³ , Seyhmus Bakir ${ }^{4}$ \\ 1, 2, 3, 4 Department of Restorative Dentistry, Faculty of Dentistry, Dicle University, Diyarbakir, Turkey.
}

\section{ABSTRACT}

\section{BACKGROUND}

Cavity disinfectants are frequently used for the elimination of bacteria that remain in the cavity, which are shown as the cause of secondary caries. However, its effect on microleakage from the tooth-restoration interface is still under investigation. The purpose of this study was to compare and evaluate the effects of the use of three different cavity disinfectants on microleakage in Class $\mathrm{V}$ composite restorations.

\section{METHODS}

For this study, 28 permanent third molar teeth without caries and restoration were used. Class V cavities of $4 \mathrm{~mm} \times 3 \mathrm{~mm} \times 3 \mathrm{~mm}$ were prepared on the buccal surfaces of each tooth. The teeth were randomly divided into 4 groups, with 7 teeth in each group. No cavity disinfectant was applied to the teeth in group 1. Tubulicid Red Label (Dental Therapeutics AB, Sweden) cavity disinfectant was applied to the 2nd group teeth, Cavity Cleanser (BISCO Inc., USA) cavity disinfectant to the 3rd group teeth, and Oxygenated Water (Dermosept, Turkey) cavity disinfectant to the 4th group teeth. Composite resin with universal adhesive and nanohybrid filler was applied to all samples in the groups in accordance with the recommendations of the manufacturers, and finishing and polishing processes were performed. Then, the thermal cycle (NOVA, Konya, Turkey) procedure was applied. After the restorations were covered with nail polish, they were kept in a $5 \%$ basic fuchsin solution. The teeth were cut vertically in the buccolingual direction and examined with a stereomicroscope at $\mathrm{x} 40$ magnification. The results were statistically evaluated with Kruskal-Wallis and Mann-Whitney U tests.

\section{RESULTS}

When the microleakage scores were compared between the control group and the groups treated with Tubulicid Red Label (p:0.204), Cavity Cleanser (p:0.204) and Oxygenated Water (P: 0.788), it was determined that there was no statistically significant difference $(\mathrm{P}>0.05)$.

\section{CONCLUSIONS}

It was determined that different cavity disinfectants applied in Class V cavities did not have a negative effect on microleakage and the closest results to the control group were seen in the group where cavity cleanser disinfectant containing $2 \%$ chlorhexidine digluconate was applied.

\section{KEY WORDS}

Cavity Disinfectants, Class V Cavity, Microleakage.
Corresponding Author:

Samican Unal,

Department of Restorative Dentistry,

Faculty of Dentistry, Dicle University,

Diyarbakir, Turkey.

E-mail:samican1507@hotmail.com

DOI: $10.14260 / j e m d s / 2021 / 759$

How to Cite This Article:

Unal S, Akbiyik SY, Bakir EP, et al. Effect of different cavity disinfectants on microleakage. J Evolution Med Dent Sci 2021;10(44):3752-3756, DOI: 10.14260/jemds/2021/759

Submission 04-09-2021,

Peer Review 30-10-2021,

Acceptance 06-11-2021,

Published 30-11-2021.

Copyright (C) 2021 Samican Unal et al. This is an open access article distributed under Creative Commons Attribution License [Attribution 4.0 International (CC BY 4.0)] 


\section{BACKGROUND}

Caries is one of the most common dental problems affecting all ages. Success in conservative dental treatments depends entirely on removing the infected dentin tissue and providing a good seal. During the polymerization of composite resins, shrinkage may occur between the tooth and the restoration margins, which may cause marginal leakage, post-operative sensitivity and secondary caries. ${ }^{1}$

Procedures for the treatment of dental caries do not always ensure the removal of cariogenic microorganisms from the cavity. The problems caused by edge leakage are exacerbated by the fact that the cavity cannot be completely freed from microorganisms during treatment. ${ }^{2}$ Literature studies report that the microorganisms remaining in the prepared tooth cavity can survive for a long time and may cause post-operative sensitivity, pulp damage, secondary caries and discolouration due to microleakage. ${ }^{3-5}$ Therefore, the elimination of microorganisms from cavity surfaces is of great importance. Today, researchers recommend the use of antibacterial cavity disinfectants and restorative materials to prevent the formation of caries caused by bacteria remaining in the cavity.6-11

The biggest problem that may occur in the use of cavity disinfectants and adhesive agents together is that they may adversely affect the bonding of the hydrophilic resin to the dentin tissue. There are many studies in the literature on this subject. Some researchers have argued that the use of cavity disinfectants creates a moisturizing effect, which increases the bonding and sealing to dentin. ${ }^{12}$ However, it has been reported in studies that the content of cavity disinfectants, the adhesive agent used together, and the application procedure of the restorative material affect the bonding differently. ${ }^{13,14}$

Tubulicid Red Label (Dental Therapeutics AB, Sweden) cavity disinfectant used in our study contains $1 \%$ sodium fluoride, $0.2 \%$ EDTA and $0.1 \%$ benzalkonium chloride. This disinfectant, which is preferred for surface cleaning with fluoride, helps to remove debris without opening the dentinal tubules during preparation. ${ }^{15}$ When the studies were examined, it was stated that $2 \%$ and $3 \%$ benzalkonium chloride agent inhibited hybrid layer and resin tag formation. ${ }^{16,17}$

Cavity Cleanser (BISCO Inc, USA) is a cavity disinfectant containing $2 \%$ chlorhexidine digluconate. Cavity Cleanser, which also has the effect of moisturizing the cavity, is recommended to be used before applying the adhesive agent to the cavity. ${ }^{18}$ Studies suggest that the use of $2 \%$ chlorhexidine before the restoration material is placed in the cavity helps to reduce residual caries and postoperative sensitivity. A study reports that the application of chlorhexidine to the cavity does not impair the sealing ability and adhesion strength of the adhesive material. ${ }^{19}$

Oxygenated Water (Dermosept, Turkey) is a cavity disinfectant containing $3 \%$ hydrogen peroxide, showing antiseptic properties. Thanks to its foaming effect, it comes to the fore in cavity cleaning. This solution, which can also be used in the septic socket and root canal cleaning, is frequently preferred before the placement of the restorative material in the cavity. ${ }^{20}$ However, in studies examining the bond strength of adhesive agents applied after the use of hydrogen peroxide to enamel, it was found that hydrogen peroxide adversely affected the bonding. 13,21

The purpose of this study was to compare and evaluate the effects of the use of three different cavity disinfectants on microleakage in Class V composite restorations.

\section{METHODS}

Cavity preparations and restorations of the teeth used in our study were carried out in Dicle University Faculty of Dentistry, Department of Restorative Dentistry, while other tests and examinations were carried out at Dicle University Science and Technology Application and Research center. Study duration was from 13 July 2020 to 18 September 2020.

\section{Ethics Statement}

Ethics Committee Approval was obtained with protocol number 2021-37 at the meeting of the Ethics Committee of Dicle University, Faculty of Dentistry dated 26/05/2021

\begin{tabular}{|ccc|}
\hline Product Trade Name & Manufacturer & Lot No \\
Cavity Cleanser & BISCO Inc., USA & 1900000744 \\
Tubulicid Red Label & Dental Therapeutics AB, Sweden & 3111151227 \\
Oxygenated Water & Dermosept, Turkey & D0072018 \\
Single Bond Universal adhesive & 3M ESPE, USA & 3424447 \\
Filtek Z200 & 3M ESPE, USA & N997960 \\
\hline \multicolumn{2}{|c|}{ Table 1. Materials Used in the Study } \\
\hline
\end{tabular}

It is planned to compare the microleakage in use with Universal adhesive agent (Single Bond universal adhesive) and nanohybrid composite resin (Filtek Z200) of cavity disinfectants containing $0.1 \%$ benzalkonium chloride (Tubulicid Red Label), $2 \%$ chlorhexidine digluconate (Cavity Cleanser) and $3 \%$ hydrogen peroxide (Oxygenated Water) in the study design. The number of samples in the groups was determined as seven, providing sufficient data for statistical analysis. For our study, 28 permanent third molar teeth, which were extracted for orthodontic or periodontal reasons, without caries and restoration were used. After the soft tissue residues on the surfaces of the teeth after extraction were removed with the help of a sharp excavator, it was examined whether there were cracks or fractures on the tooth and root surfaces. The teeth were kept in distilled water at $37^{\circ} \mathrm{C}$ until the cavities were opened. Class V cavities with a mesiodistal width of $4 \mathrm{~mm}$, a gingivo-occlusal width of $3 \mathrm{~mm}$ and a depth of $3 \mathrm{~mm}$ were prepared with a fissure-tipped diamond bur (Diatech, Swiss Dental, Heerbrugg, Switzerland) on the buccal surface of each tooth under water cooling. The bur used in every five cavities was renewed and care was taken to avoid deviations in cavity dimensions by using a millimetric tipped periodontal probe during cavity preparations. The prepared teeth were randomly divided into 4 groups, with 7 teeth in each group.

\section{Group 1}

No cavity disinfectant was applied to the Class V cavity surface of the teeth in this group and formed the control group. Single Bond Universal adhesive (3M ESPE, USA) was applied to the dentin surface by rubbing for 20 seconds. After drying with light air for 5 seconds, it was polymerized for 10 
seconds with a $1000 \mathrm{~mW} / \mathrm{cm} 2$ LED light device (Light Emitting Diode -Elipar Freelight, 3M ESPE, Germany). Then, nano-hybrid filled composite resin (Filtek Z200, A2, 3M ESPE, USA) was applied by layering method and polymerized with LED light for 20 seconds.

\section{Group 2}

It was applied to the Class V cavity surface of the teeth with a Tubulicid Red Label (Dental Therapeutics AB, Sweden) bonding brush for 20 seconds and left for 20 seconds. Single Bond Universal adhesive and composite resin with nanohybrid filler were applied to all samples without any washing process and polymerized in accordance with the recommendations of the manufacturers.

\section{Group 3}

It was applied to the Class $\mathrm{V}$ cavity surface of the teeth with a Cavity Cleanser (BISCO Inc, USA) bonding brush for 20 seconds and left for 20 seconds. Single Bond Universal adhesive and composite resin with nanohybrid filler were applied to all samples without any washing process and polymerized according to the recommendations of the manufacturers.

\section{Group 4}

It was applied to the Class V cavity surface of the teeth with an Oxygenated Water (Dermosept, Turkey) bonding brush for 20 seconds and left for 20 seconds. Single Bond Universal adhesive and composite resin with nanohybrid filler were applied to all samples without any washing process and polymerized as per the recommendations of the manufacturers.

After finishing and polishing the teeth in all restored experimental groups using fine-grained diamond burs and aluminium oxide coated discs (Sof-Lex, 3M ESPE, St.Paul, MN, USA), the prepared teeth were stored in a $37^{\circ} \mathrm{C}$ humid incubator for 24 hours. At the end of this period, 1,000 thermal cycles (NOVA, Konya, Turkey) were applied to all the teeth, waiting for 30 seconds in heat baths using $5^{\circ} \mathrm{C}$ to $55^{\circ} \mathrm{C}$ $\left( \pm 2^{\circ} \mathrm{C}\right)$ tap water. Then, after applying 2 coats of nail polish to all surfaces of the teeth, leaving the restoration edges up to 1 $\mathrm{mm}$ exposed, the teeth were kept in an oven at $37^{\circ} \mathrm{C}$ for 24 hours in a $5 \%$ basic fuchsin solution. Then, the teeth were divided into two equal parts transversely in the buccolingual direction, passing through the middle of the restoration under water cooling with the aid of a $0.2 \mathrm{~mm}$ thick diamond separator (Isomet, Buehler Ltd, Lake Bluff, IL, USA). Paint leakage on the restoration edges of each piece was evaluated by two different researchers using a stereomicroscope (Olympus SZ60, Tokyo, Japan) at $\times 40$ magnification and scored (Figure 1).

\section{Scoring Table for Class V Cavities}

Score 0: No leakage

Score 1: Penetration to a depth of $0-1 \mathrm{~mm}$ of the cavity depth Score 2: Penetration to a depth of 1-2 mm of the cavity depth Score 3: Penetration of more than $2 \mathrm{~mm}$ of the cavity depth without reaching the axial wall

Score 4: Penetration of more than $2 \mathrm{~mm}$ of the cavity depth up to the axial wall.

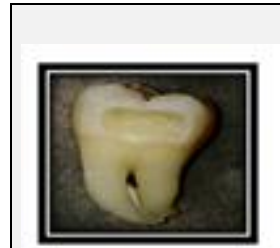

(a)

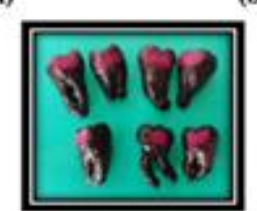

(d)

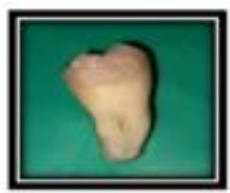

(b)

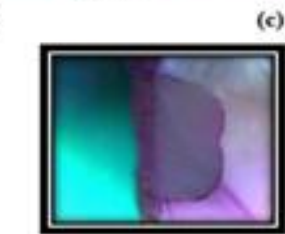

(e)

Figure 1. Application Stages of the Study (a: Class V Cavity Opened to the Buccal Surface of the Teeth, b: Application of Cavity Disinfectant and Composite with Nano-Hybrid Filler, c: Application of Two Layers of Nail Polish, d: Teeth Soaked in 5 \% Basic Fuchsin Solution, e: Viewing at $\times 40$ Magnification with a Stereo Microscope)

\section{Statistical Analysis}

Obtained microleakage scores were evaluated using KruskalWallis statistical tests for intergroup comparisons and MannWhitney U statistical tests for pairwise comparisons. While interpreting the results, 0.05 was used as the significance level; It was stated that there was a significant difference in the case of $\mathrm{P}<0.05$, and there was no significant difference in the case of $\mathrm{P}>0.05$.

\section{RESULTS}

Microleakage scores according to the cavity disinfectants used in our study are given in Table 2. Kruskal-Wallis test results showed that the difference between microleakage values was not significant in the groups in which cavity disinfectants were used $(\mathrm{P}>0.05)$.

\begin{tabular}{|cccccc|}
\hline \multirow{2}{*}{ Groups } & \multicolumn{5}{c|}{ Scoring Table for Class V Cavities } \\
& Skor 0 & Skor 1 & Skor 2 & Skor 3 & Skor 4 \\
Group 1 (Control) & 5 & 1 & 1 & 0 & 0 \\
Group 2 (Tubulicid Red Label) & 2 & 2 & 2 & 1 & 0 \\
Group 3 (Cavity Cleanser) & 4 & 1 & 1 & 1 & 0 \\
Group 4 (Oxygenated Water) & 2 & 2 & 1 & 1 & 1 \\
\hline Table 2. Distribution of Microleakage Scores of Teeth in Four Groups \\
\hline
\end{tabular}

\section{DISCUSSION}

In restorative dental treatments, the use of resin-containing restorative materials is increasing due to the widespread aesthetic expectations of patients after treatment. ${ }^{12}$ However, polymerization shrinkage of resin-containing restorative materials and the presence of residual bacteria can cause microleakage, secondary caries and marginal discolouration. Although many materials have been developed to reduce polymerization shrinkage, this situation cannot be completely avoided. Therefore, it is necessary to remove the bacteria that cause caries from the cavity. For this purpose, it is recommended to use antibacterial effective restorative materials and cavity disinfectants. ${ }^{22}$ 
The antibacterial activity of cavity disinfectants is formed by agents with high disinfectant properties such as chlorhexidine, sodium hypochlorite, hydrogen peroxide. The use of solutions containing these agents in appropriate doses after cavity preparation can ensure the elimination of microorganisms remaining in the cavity and, accordingly, greatly reduce the formation of bacterial residual caries. ${ }^{23}$ Private et al. in their study comparing the antibacterial effects of cavity solutions containing $2 \%$ chlorhexidine, $3 \% \mathrm{H} 2 \mathrm{O} 2$ and $32 \%$ benzalkonium chloride, reported that all disinfectants had antibacterial effects. ${ }^{24}$

The biggest problem in limiting the use of cavity disinfectants is the thought that they will bind poorly to dentin. However, studies show that the use of cavity disinfectant does not cause edge leakage and does not have a negative effect on bonding to dentin. ${ }^{25}$ Ercan et al. in their study, in which they examined the connection of cavity disinfectants containing hydrogen peroxide and chlorhexidine to dentin, reported that disinfectants did not have a negative effect on the bonding. ${ }^{13}$

Celik et al. in their similar studies on Class $\mathrm{V}$ cavities found that chlorhexidine-containing cavity disinfectants did not adversely affect the bonding. ${ }^{11}$ Studies on leakage formation on Class $\mathrm{V}$ cavities in the literature show that chlorhexidine does not have a negative effect.10,26 Dalli et al. in a similar study, found that the application of chlorhexidinecontaining cavity disinfectants in different forms and ratios before self-etching adhesive did not have a negative effect on microleakage. ${ }^{27}$ Turkun et al. in their study examining the effect of the use of Consepsis and Tubulicid Red Label cavity disinfectants with adhesives on microleakage, stated that Consepsis containing chlorhexidine and Tubulicid Red Label cavity disinfectants containing benzalkonium chloride did not have a negative effect on microleakage. ${ }^{28}$ In addition, in a study on primary teeth, it was reported that cavity disinfectant containing chlorhexidine increased the marginal leakage. We think that this result may be due to the weak bonding of the adhesive resins to the primary teeth compared to the permanent teeth. ${ }^{29}$

In a recent study, it was seen that the cavity disinfectant containing $2 \%$ chlorhexidine gluconate caused less microleakage than other cavity disinfectants, and it was stated that the effect of the cavity disinfectants used in the study on microleakage was not statistically significant. ${ }^{30}$ In addition, Lugassy et al. stated that the application of $2 \%$ chlorhexidine gluconate disinfectant before the use of glass ionomer restorative materials did not have a negative effect on microleakage, but the result obtained was not statistically significant. ${ }^{31}$ The fact that the cavity disinfectants used in our study did not have a statistically significant effect on microleakage supports the literature studies.

Adequate application of adhesive systems is of great importance in bonding the tooth to the restorative material after the application of cavity disinfectant. These adhesive systems are divided into two groups according to their clinical applications as total-etch and self-etch adhesive systems. Total etch adhesive systems, in which enamel and dentin are etched together with acid, are subjected to washing and drying processes. Self-etch adhesives, also called self-etch adhesive systems, are systems that do not have an acid-washing stage and are developed to reduce application time and technical sensitivity. Universal adhesives developed later are multi-purpose adhesive systems that can be used with two-step total-etch, one-step self-etch or selective etching techniques. Studies do not show a common view on which type of adhesive system reduces microleakage. While some studies argue that the use of a total-etch adhesive system in Class $\mathrm{V}$ cavities will cause less edge leakage than the use of self-etch adhesive systems, ${ }^{32,33}$ some studies have argued that changing the type of adhesive systems applied does not have a statistically significant effect on microleakage.11,34 In our study, Single Bond Universal adhesive, which can be used with both techniques, was preferred.

In dentistry, dyes such as $5 \%$ basic fuchsin solution, $50 \%$ silver nitrate and $0.2-2 \%$ methylene blue are used in edge leak examinations. The reason why $5 \%$ basic fuchsin solution was preferred in our study is that it is widely used, inexpensive, easy to apply and practical to prepare. ${ }^{35-38}$

\section{CONCLUSIONS}

Our study showed that the application of cavity disinfectants before the adhesive system did not have a negative effect on the amount of microleakage, and the lowest microleakage score was found in cavities where chlorhexidine-containing cavity disinfectant was applied. We think that supporting the study with in-vivo studies will contribute to the literature.

\section{Limitation}

It is planned that the next stage of our study, which was carried out in vitro, with extracted caries and non-restorative teeth, will be an animal experiment. The fact that the Covid 19 epidemic makes patient follow-up difficult makes it hard to conduct clinical studies. With the loss of effect of the epidemic, clinical researches

will be carried out more healthily. The stereo microscope was used as the imaging method, and limited research budgets restrict the use of different imaging methods.

Data sharing statement provided by the authors is available with the full text of this article at jemds.com.

Financial or other competing interests: None.

Disclosure forms provided by the authors are available with the full text of this article at jemds.com.

This study was presented at International Congress of Health Research (25-28 August 2021) online.

\section{REFERENCES}

[1] Ferracane JL. Resin composite--state of the art. Dent Mater 2011;27(1):29-38.

[2] Darabi F, Eftekhari M. Effect of chlorhexidine on microleakage of composite restorations. Journal of Dentistry of Tehran University of Medical Sciences 2009;6(1):16-22.

[3] Roberson TM, Heymann HO, Ritter AV. Introduction to composite restorations. 'Sturdevant's, The art and science of operative dentistry' (Ed. T.M. Robenson, H.O. Heymann, E.J. Swift), IV. Bask, Mosby Inc.,Missouri 2002:473-99. 
[4] Condon JR, Ferracane JL. Assessing the effect of composite formulation on polymerization stress. J Am Dent Assoc 2000;131(4):497-503.

[5] Kubo S, Yokota H, Sata Y, et al. The effect of flexural load cycling on microleakage of cervical resin composites. Oper Dent 2001;26(5):451-9.

[6] Türkün LŞ, Türkün M, Ateş M. Antibacterial activity of a self-etching adhesive system containing "MDPB". G.Ü Dişhek Fak Derg 2003;20:41-6.

[7] Eligüzeloğlu E, Üçtaşlı MB, Ömürlü $H$, et al. The effects of different types of adhesive systems on the microleakage of class v compomer restorations. G.Ü Diş Hek Fak Derg 2006;23:71-7.

[8] Yavuz İ, Aydın HA, Kaya S. New method for measurement of microleakage. T Klin Diş Hek Bil 2003;9:79-85.

[9] El-Housseing AA, Jamjoum H. The effect of caries detector dyes and cavity cleansing agent on composite resin bonding to enamel and dentin. J Clin Pediatr Dent 2000;21:57-63.

[10] Geraldo-Martins VR, Robles FRP, Matos AB. Chlorhexidine's effect on sealing ability of composite restorations following Er: YAG laser cavity preparation. J Contemp Dent Pract 2007;8(5):26-33.

[11] Çelik Ç, Özel Y, Karabulut E. Effect of cavity disinfectant application on microleakage of different dentin adhesive systems. Atatürk Üniv Diş Hek Fak Derg 2007;17:7-12.

[12] Totu Fİ. Kavite dezenfektanlarinin ve antibakteriyel dentin bonding sisteminin, kompomer restorasyonlarin mikrosizinti ve bağlanma kuvvetlerine etkisi. Doktora Tezi 2006;125-39.

[13] Ercan E, Erdemir A, Zorba YO, et al. Effect of different cavity disinfectants on shear bond strength of composite resin to dentin. J Adhes Dent 2009;11(5):343-6.

[14] Say EC, Koray F, Tarım B, et al. In vitro effect of cavity disinfectants on the bond strength of dentin bonding systems. Quintessence Int 2004;35(1):56-60.

[15] Türkün M, Türkün LŞ, Ergücü Z, et al. Is an antibacterial adhesive system more effective than cavity disinfectants? Am J Dent 2006;19(3):166-70.

[16] Sharma V, Rampal P, Kumar S. Shear bond strength of composite resin to dentin after application of cavity disinfectants - SEM study. Contemp Clin Dent 2011;2(3):155-9.

[17] Puppin-Rontani R, Caetano E, Garcia-Godoy F, et al. Effect of antimicrobial agents on the micromorphology of primary dentin. J Clin Pediatr Dent 2001;25(2):137-41.

[18] Gupta J, Thomas MS, Radhakrishna M, et al. Effect of silver diamine fluoride-potassium iodide and $2 \%$ chlorhexidine gluconate cavity cleansers on the bond strength and microleakage of resin-modified glass ionomer cement. J Conserv Dent 2019;22(2):201-6.

[19] Siso HS, Kustarci A, Göktolga EG. Microleakage in resin composite restorations after antimicrobial pretreatments: effect of KTP laser, chlorhexidine gluconate and clearfil protect bond. Oper Dent 2009;34(3):321-7.

[20] Menezes RP, Silva PD, Leal PC, et al. Impact of 35\% hydrogen peroxide on color and translucency changes in enamel and dentin. Braz Dent J 2018;29(1):88-92.

[21] Montalvan E, Vaidyanathan T, Shey Z, et al. The shear bond strength of acetone and ethanol-based bonding agents to bleached teeth. Pediatr Dent 2006;28(6):531-6.
[22] Türkün M, Türkün LS, Ateş M. Antibacterial activity of cavity disinfectants. Balk J Stom 2004;8(3):214-9.

[23] Feuerstein O, Matalon S, Slutzky H, et al. Antibacterial properties of self-etching dental adhesive systems. J Am Dent Assoc 2007;138(3):349-54.

[24] Özel E, Yurdagüven H, Say EC, et al. Evaluation the antibacterial activity of disinfectant solutions and phosphoric acids against streptococcus mutans. Hacettepe Dişhekimliği Fakültesi Dergisi 2005;29(4):814.

[25] Piva E, Martos J, Demarco FF. Microleakage in amalgam restorations: influence of cavity cleanser solutions and anticariogenic agents. Oper Dent 2001;26(4):383-8.

[26] Sung EC, Chan SM, Tai ET, et al. Effects of various irrigation solutions on microleakage of Class $\mathrm{V}$ composite restorations. J Prosthet Dent 2004;91(3):2657.

[27] Dallı M, Sahbaz C, Bahsi E, et al. The effects of disinfectants on microleakage in class $V$ cavity: in vitro studies. Journal of Dental Faculty of Atatürk University 2009;19(1):14-9

[28] Türkün M, Türkün LS, Kalender A. Effect of cavity disinfectants on the sealing ability of nonrinsing dentinbonding resins. Quintessence Int 2004;35(6):469-76.

[29] Tulunoğlu Ö, Ayhan H, Ölmez A, et al. The effect of cavity disinfectants on microleakage in dentin bonding systems. J Clin Pediatr Dent 1998;22(4):299-305.

[30] Lokhande NM, Manjunath SH, Patil AK, et al. Effect of different cavity disinfectants on marginal sealing ability of a seventh-generation dentin bonding agent: an in vitro study. J Contemp Dent Pract 2020;21(3):242-8.

[31] Lugassy D, Segal P, Blumer S, et al. Effect of two traditional polyacrylic acid conditioners and $2 \%$ chlorhexidine digluconate on cavosurface microleakage of glass ionomer restorations. J Clin Pediatr Dent 2018;42(4):287-91.

[32] Abo T, Uno S, Sano H. Comparison of bonding efficacy of an all-in-one adhesive with a self-etching primer system. Eur J Oral Sci 2004;112(3):286-92.

[33] Sensi LG, Lopes GC, Monteiro S, et al. Dentin bond strength of self-etching primers/adhesives. Oper Dent 2005;30(1):63-8.

[34] Santini A, Ivanovic V, Ibbetson $R$, et al. Influence of marginal bevels on microleakage around Class $V$ cavities bonded with seven selfetching agents. Am J Dent 2004;17(4):257-61.

[35] Karadağ S. Microleakage evaluation techniques and factors effecting microleakage. Atatürk Üniv Diş Hek Fak 2005;15:80-7.

[36] Piva E, Meinhardt L, Demarco FF, et al. Dyes for caries detection: influence on composite and compomer microleakage. Clin Oral Investig 2002;6(4):244-8.

[37] Loguercio AD, de Oliveira Bauer JR, Reis A, et al. In vitro microleakage of packable composites in Class II restorations. Quintessence Int 2004;35(1):29-34.

[38] Williams PT, Schramke D, Stockton L. Comparison of two methods of measuring dye penetration in restoration microleakage studies. Oper Dent 2002;27(6):628-35. 